\title{
Evaluation of anxiety levels among dentists working during the COVID-19 pandemic
}

\author{
D Tunahan Döken, ${ }^{1}$ (D) Melike Bayram, ${ }^{1}$ (D) Emre Bayram, ${ }^{1}$ \\ (D) Hilal Ekmen, ${ }^{1}$ (i) Şeyma Nur Gerçekcioğlu' ${ }^{1}$ \\ 'Department of Endodontics, Tokat Gaziosmanpaşa University Faculty of Dentistry, Tokat, Turkey
}

\begin{abstract}
Purpose: To use the "state and trait anxiety scale" to examine the anxiety levels among dentists caring for patients during the coronavirus disease 19 (COVID-19) pandemic, and compare it to the levels observed in the pre-pandemic period.
\end{abstract}

Methods: This study included 500 dentists working during and before the COVID-19 pandemic, and participants were asked to complete a questionnaire form containing 40 questions using Google Forms. A score ranging between $1 /-1$ and $4 /-4$ was assigned to each question based on whether it was a positive or negative characteristic, and a constant of 50 was added to the total score. A higher anxiety score indicated an increase in the anxiety levels of the individual.

Results: A statistically significant difference in state-trait anxiety inventory scores was observed between men and women $(p<0.001)$. The state anxiety scale scores were seen to decrease with increasing age $(p<0.001)$. No statistically significant differences in trait anxiety scale scores were observed between institutions, although dentists working in public hospitals exhibited higher state anxiety scale scores $(p<0.05)$. Dentists with $1-4$ years of experience had the highest trait anxiety scale scores, while those with $>=10$ years of experience demonstrated lower state anxiety scale scores $(p<0.05)$.

Conclusion: The levels of anxiety among dentists were seen to increase after the COVID-19 pandemic. Keywords: Anxiety level, COVID-19, dentist, pandemic.

\section{Introduction}

Coronavirus disease 19 (COVID-19), a respiratory infection caused by a new virus belonging to the coronavirus family (1), was first detected on December $31^{\text {th }}, 2019$ in Wuhan, Hubei province, China. In Turkey, the first case of COVID-19 was detected on March 10 $0^{\text {th }}, 2020$, and the first associated death occurred on March $15^{\text {th }}, 2020$. By April 2020, COVID-19 had spread throughout Turkey, as declared by the Minister of Health, Fahrettin Koca. As of
April 2021, the ongoing pandemic has caused over 137 million infections and 2.9 million deaths globally, with the corresponding numbers in Turkey being 3.9 million infections and 34,000 deaths $(2,3)$.

In an attempt to control the spread of COVID-19, various restrictive measures were implemented globally, and the consequent effects on normal life led to an increase in the incidence of psychological disorders such as anxiety, de-

Cite this article as: Döken T, Bayram M, Bayram E, Ekmen H, Gerçekcioğlu ŞN. Evaluation of anxiety levels among dentists

working during the COVID-19 pandemic. Turk Endod J 2021;6:45-49.

Correspondence: Melike Bayram. Department of Endodontics, Tokat Gaziosmanpaşa University

Faculty of Dentistry, Tokat, Turkey.

Tel: +90 356 - 2124222 e-mail: melikealaca@yahoo.com

Submitted: April 19, 2021 Accepted: June 28, 2021

(C)2021 Turkish Endodontic Society 
pression, and post-traumatic stress disorder in the general population (4-8).

The primary route of transmission of COVID-19 is via droplets and aerosols, which are generated frequently during dental treatments. This puts dentists, patients, and staff at serious risk of contracting infection (9), resulting in both physical and psychological stress among healthcare professionals (10). A recent review evaluating the effects of the COVID-19 pandemic on medical personnel found increased incidence of depressive symptoms and anxiety among healthcare workers globally (11).

The "State and trait anxiety scale" developed by Spielberger et al. in 1970 is a Likert-type questionnaire scale that uses 20 questions to separately measure the levels of state and trait anxiety in individuals. The total score ranges between 20 and 80 , with a higher score indicating greater levels of anxiety (12), and a 4-point scale ranging from "none" to "totally" is used to assess the final scores. The validity and reliability of this questionnaire in Turkey was first assessed by Öner in 1977, and the test was adapted to Turkish society by Öner and Le Compte in 1985 (13).

The aim of the current study was to use the "State and trait anxiety scale" to examine the levels of anxiety among dentists caring for patients during the COVID-19 pandemic, and to compare it to the levels observed in the pre-pandemic period. The hypothesis was that the COVID-19 pandemic would result in increased levels of anxiety among dentists.

\section{Materials and Methods}

This study was approved by the Tokat Gaziosmanpaşa University Clinical Research Ethics Committee (reference number: 21-KAEK-013). A power analysis was carried out using G Power 3.1.9.2, and a study sample of 500 individuals was considered sufficient for an effect size of 0.71 , error level of 0.05 , and study power of $95 \%$.

The questionnaire survey was carried out between February 2021 and March 2021 using Google Forms, and 700 dentists who treated patients during and before the COVID-19 pandemic were included in the study. The response rate was $84 \%(n=500)$, and the survey forms included 40 questions (Appendix 1). Positive scores (which increases the total anxiety score) were assigned for articles $3,4,6,7,9,12,13,14,17$, and 18 , while negative scores (which decreases the total anxiety score) were given for articles $1,2,5,8,10,11,15,16,19$, and 20 . In the trait anxiety scale, questions $21,26,27,30,33,36$, and 39 include negative expressions. A score ranging between $1 /-1$ and $4 /-4$ was given for each question based on whether it was a positive or negative characteristic, and a constant of
50 was added to the total score. The final score ranged between 20 and 80 , with a higher total anxiety score indicating greater levels of anxiety in the individual completing the questionnaire (14-16). A constant of 35 was added to the trait anxiety scores. The total score value obtained from both scales ranged between 20 and 80, with higher scores indicating greater anxiety (15). The data obtained were recorded as percentages using descriptive statistical methods in Microsoft Excel.

\section{Statistical Method}

The descriptive characteristics of the study groups were analyzed, and quantitative data were presented as mean \pm standard deviation. Differences between groups were analyzed using the independent samples t-test or MannWhitney $U$, and one way analysis of variance tests. A pvalue $<0.05$ was considered to be statistically significant, and all analyses were carried out using a statistical software (IBM SPSS Statistics 19, SPSS inc., IBM, Somers, NY).

\section{Results}

The distribution of gender, age, and institutional and professional experience of the dentists participating in the study are shown in Table 1.

A significant difference in the trait anxiety scale and state anxiety scale scores was observed between males and females ( $\mathrm{p}<0.001$; Table 2$)$.

No significant differences in trait anxiety scale scores were observed between different age groups. With regard to the state anxiety scale scores, no statistically signifi-

Table 1. Descriptive characteristics of study sample $(n=500)$

\begin{tabular}{lcc} 
& $\mathbf{n}$ & $\%$ \\
\hline $\begin{array}{l}\text { Gender } \\
\text { Male }\end{array}$ & \\
$\quad$ Female & 131 & 26.2 \\
Age & 369 & 73.8 \\
20-24 & & \\
$25-29$ & 79 & 15.8 \\
30-34 & 198 & 39.6 \\
35-39 & 80 & 16.0 \\
>40 & 82 & 16.4 \\
Establishment & 61 & 12.2 \\
Public hospital & & \\
Private clinic & 180 & 36.0 \\
University hospital & 133 & 26.6 \\
Experience & 187 & 37.4 \\
1-4 years & & \\
5-9 years & 256 & 51.2 \\
$>10$ years & 73 & 14.6 \\
\hline
\end{tabular}


cant differences were observed between the 20-24 and 25-29 year age groups and the 35-39 and $>40$ year age groups. However, a significantly lower level of anxiety was observed in individuals aged $35-39$ and $>40$ years compared to those aged $20-24$ and $25-29$ years. Individuals between the ages of 30 and 34 years exhibited anxiety scores similar to that exhibited by other groups $(\mathrm{p}<0.001 ;$ Table 3$)$.

No statistically significant differences in trait anxiety scale scores were observed between institutions. In contrast, evaluation of the state anxiety scale scores showed that dentists working in oral and dental health centers exhibited a significantly higher level of anxiety compared to those working in private clinics. Moreover, the anxiety levels of dentists working in the university hospital was found to be similar to that exhibited by dentists working in other establishments $(\mathrm{p}<0.05$; Table 4$)$.

Table 2. Distribution of Anxiety Scale Scores by gender $(n=500)$

\begin{tabular}{lccc} 
& \multicolumn{2}{c}{ Gender } & p \\
\cline { 2 - 3 } & $\begin{array}{ccc}\text { Male } \\
(\mathbf{n}=\mathbf{1 3 1})\end{array}$ & $\begin{array}{c}\text { Female } \\
(\mathbf{n}=\mathbf{3 6 9 )}\end{array}$ & \\
\hline Trait Anxiety Scale Form Score & $32.79 \pm 2.66$ & $34.01 \pm 2.63$ & $<0.001^{*}$ \\
State Anxiety Scale Form Score & $43.08 \pm 9.72$ & $50.11 \pm 10.35$ & $<0.001^{*}$ \\
\hline
\end{tabular}

${ }^{*} p<0.05$ is considered significant.
Dentists with 1 to 4 years of experience exhibited significantly higher trait anxiety scale scores compared to those with 10 or more years of experience, while those with 5-9 years of experience exhibited scores similar to the other groups. Dentists with 1-4 and 5-9 years of experience exhibited similar state anxiety scale scores, while those with 10 or more years of experience demonstrated lower levels of anxiety $(\mathrm{p}<0.05$; Table 5$)$.

\section{Discussion}

Dentistry is an extremely stressful profession that requires intensive theoretical knowledge combined with interpersonal communication and clinical skills $(17,18)$. Stress often has psychological consequences such as high levels of burnout (19-21), disappointment, mental disturbances related to mood changes, and decreased concentration $(22,23)$. It may also affect physical health, resulting in increased incidence of illness, anorexia, and digestive problems $(19,24)$. The rapid increase in the number of affected countries and individuals during the COVID-19 pandemic has resulted in increased feelings of uncertainty and anxiety about contracting the infection $(25,26)$. The nature of this disease, the long incubation period (up tol4 days), the fact that it may present asymptomatically or severely enough to cause death, and the lack of definitive treatments or vaccines significantly contribute to the increased

Table 3. Distribution of Anxiety Scale Scores by age $(n=500)$

\begin{tabular}{|c|c|c|c|c|c|c|}
\hline & \multicolumn{5}{|c|}{ Age } & \multirow[t]{2}{*}{$\mathbf{p}$} \\
\hline & $\begin{array}{c}20-24 \\
(n=79)\end{array}$ & $\begin{array}{c}25-29 \\
(n=198)\end{array}$ & $\begin{array}{c}30-34 \\
(n=80)\end{array}$ & $\begin{array}{c}35-39 \\
(n=82)\end{array}$ & $\begin{array}{c}>40 \\
(n=61)\end{array}$ & \\
\hline Trait Anxiety Scale Form Score & $33.99 \pm 3.16$ & $34.01 \pm 2.61$ & $33.18 \pm 2.63$ & $33.38 \pm 2.68$ & $33.36 \pm 2.25$ & 0.071 \\
\hline State Anxiety Scale Form Score & $50.76 \pm 9.99^{\text {(a) }}$ & $49.49 \pm 9.99^{(a)}$ & $48.68 \pm 10.97^{(a b)}$ & $45.04 \pm 9.94^{(b)}$ & $44.9 \pm 12.41^{(b)}$ & $<0.001^{*}$ \\
\hline
\end{tabular}

${ }^{*} p<0.05$ is considered significant. ${ }^{* *}$ Different letters indicate statistically significant differences.

Table 4. Distribution of Anxiety Scale Scores by establishment $(n=500)$

\begin{tabular}{lccc} 
& \multicolumn{3}{c}{ Establishment } \\
\cline { 2 - 4 } & Public hospital $(\mathbf{n = 1 8 0})$ & Private clinical $(\mathbf{n = 1 3 3 )}$ & University hospital $(\mathbf{n}=\mathbf{1 8 7})$ \\
\hline Trait Anxiety Scale Score & $33.87 \pm 2.59$ & $33.58 \pm 2.51$ & $33.59 \pm 2.92$ \\
State Anxiety Scale Score & $49.81 \pm 11.1^{\text {(a) }}$ & $46.76 \pm 11.34^{(\mathrm{b})}$ & 0.518 \\
\hline
\end{tabular}

${ }^{*} p<0.05$ is considered significant. ${ }^{* *}$ Different letters in table indicate statistically significant differences.

Table 5. Distribution of Anxiety Scale Scores by experience $(n=500)$

\begin{tabular}{|c|c|c|c|c|}
\hline & \multicolumn{3}{|c|}{ Experience } & \multirow[t]{2}{*}{$\mathbf{p}$} \\
\hline & $1-4$ years $(n=256)$ & $5-9$ years $(n=73)$ & $>10$ years $(n=171)$ & \\
\hline Trait Anxiety Scale Score & $34.02 \pm 2.76^{(\mathrm{a})}$ & $33.26 \pm 2.74^{(\mathrm{ab})}$ & $33.37 \pm 2.52^{(b)}$ & $0.016^{*}$ \\
\hline State Anxiety Scale Score & $49.61 \pm 10.11^{\text {(a) }}$ & $49.95 \pm 10.65^{(\mathrm{a})}$ & $45.55 \pm 10.94^{(b)}$ & $<0.001^{*}$ \\
\hline
\end{tabular}

${ }^{*} p<0.05$ is considered significant. ${ }^{* *}$ Different letters in table indicate statistically significant differences. 
levels of stress among healthcare professionals, especially dentists (27). Moreover, a significant lack of masks and disinfectants, sensational headlines, and false news further increase the levels of anxiety and fear (28).

To date, numerous scales such as the dental environmental stress, Beck depression inventory, and the state-trait anxiety inventory (STAI) have been used to assess the current psychological state of individuals (29). STAI-1 assesses the anxiety state of an individual at a certain time and under certain conditions, while STAI-2 is an important index determining how an individual feels regardless of the situation and circumstances (30). It also provides a more comprehensive assessment because of its contents $(29,30)$. In the current study, the STAI scales were used as they allow evaluation of anxiety over a longer period of time as well as comparison of anxiety levels during periods of psychological variability such as a pandemic.

This study aimed to compare the anxiety levels of dentists working during the COVID-19 pandemic to the levels exhibited by them in the pre-pandemic period using the "state and trait anxiety scale." This survey study relied on subjective reports provided by the dentists only. Based on the findings, the null hypothesis was rejected and the COVID-19 pandemic was found to increase the anxiety levels of dentists. This could likely be attributed to the increased risk of transmission associated with formation of droplets and aerosols during dental treatments.

Ozdede et al. and Cao et al. reported no statistically significant differences in stress levels between females and males in their study $(30,31)$. In contrast, Al-Rabiaah et al., reported significantly higher levels of stress among females compared to males (32). In the current study, a statistically significant difference in stress levels was observed between males and females, and this could be explained by the fact that females were more likely to be affected emotionally during difficult situations and to report symptoms of stress and anxiety compared to males.

A previous study found that the recorded levels of anxiety were higher among young dentists and females compared to older dentists and males. This could be attributed to the fact that older dentists were more experienced in dealing with stressful circumstances, making them more confident and less prone to anxiety (27). The findings of the current study were in agreement with this, with the anxiety levels of more experienced dentists being significantly lower than those with lesser experience.

Mahde et al., reported high anxiety levels caused by the COVID-19 pandemic among dentists, and this was particularly true for those working in the public sector compared to those working in private clinics (27). The findings of the current study were similar, with dentists working in public hospitals exhibiting higher levels of anxiety. A possible explanation for this could be the fact that dentists working in the public sector were likely to encounter more patients and were also occasionally assigned to the radiation team as part of COVID-19 measures.

A key limitation of the current study was its cross-sectional design, thus providing evidence from a single point in time during the pandemic. Further studies examining different stages of the pandemic in a larger number of countries and including more participants are required.

\section{Conclusion}

Based on the findings of this study, it can be concluded that the anxiety levels among dentists were seen to increase after the COVID-19 pandemic.

Authorship Contributions: Concept: H.E., T.D.; Design: E.B., M.B., T.D.; Supervision: E.B., Ş.N.G., M.B.; Materials: S,.N.G., T.D.; Data: T.D., E.B.; Analysis: E.B.; Literature search: Ş.N.G., T.D.; Writing: T.D., M.B., H.E.; Critical revision: M.B., E.B., T.D.

Source of Fundingः None declared.

Conflict of Interest: None declared.

Ethical Approval: The study protocol was approved by the Tokat Gaziosmanpaşa University Clinical Research Ethics Commitee (date: 14.01.2021, protocol no: 21-KAEK-013).

\section{References}

1. Cascella M, Rajnik M, Aleem A, Dulebohn SC, Di Napoli $\mathrm{R}$. Features, evaluation, and treatment of coronavirus (COVID-19). In: StatPearls. Treasure Island (FL): StatPearls Publishing; 2021.

2. World Health Organization, Turkey: WHO Coronavirus disease (COVID-19) dashboard. 2020. Available at: https://covid19.who.int/region/euro/country/tr. Accessed Apr 2021.

3. Choi EPH, Hui BPH, Wan EYF. Depression and anxiety in Hong Kong during COVID-19. Int J Environ Res Public Health 2020; 17: 3740. [CrossRef]

4. Blekas A, Voitsidis P, Athanasiadou M, et al. COVID-19: PTSD symptoms in Greek health care professionals. Psychol Trauma 2020; 12: 812-9. [CrossRef]

5. Liu CH, Zhang E, Wong GTF, Hyun S, Hahm HC. Factors associated with depression, anxiety, and PTSD symptomatology during the COVID-19 pandemic: Clinical implications for U.S. young adult mental health. Psychiatry Res 2020; 290: 113172. [CrossRef]

6. Huang Y, Zhao N. Generalized anxiety disorder, depressive symptoms and sleep quality during COVID-19 outbreak in China: a web-based cross-sectional survey. Psychiatry Res 2020; 288: 112954. [CrossRef] 
7. Salari N, Hosseinian-Far A, Jalali R, et al. Prevalence of stress, anxiety, depression among the general population during the COVID-19 pandemic: a systematic review and meta-analysis. Global Health 2020; 16:57. [CrossRef]

8. Hyland P, Shevlin M, McBride O, et al. Anxiety and depression in the Republic of Ireland during the COVID-19 pandemic. Acta Psychiatr Scand 2020; 142: 249-56.

9. Ren Y, Feng C, Rasubala L, Malmstrom H, Eliav E. Risk for dental healthcare professionals during the COVID-19 global pandemic: An evidence-based assessment. J Dent 2020; 101: 103434. [CrossRef]

10. Wu P, Fang Y, Guan Z, et al. The psychological impact of the SARS epidemic on hospital employees in China: exposure, risk perception, and altruistic acceptance of risk. Can J Psychiatry 2009; 54: 302-11. [CrossRef]

11. Bohlken J, Schömig F, Lemke MR, Pumberger M, RiedelHeller SG. COVID-19 pandemic: Stress experience of healthcare workers - a short current review. Psychiatr Prax 2020; 47: 190-7. [CrossRef]

12. Spielberger CD, Gorsuch RL, Lushene RE. Manual for state-trait anxiety inventory. California: Consulting Psychologists Press; 1970. p. 23-49.

13. Öner N, Le Compte A. Durumluk-sürekli kayg1 envanteri el kitabı. İstanbul: Boğaziçi Üniversitesi Yayınları; 1983.

14. Coşkun Y, Akkaş G. Engelli çocuğu olan annelerin sürekli kaygı düzeyleri ile sosyal destek algıları arasındaki ilişki. Ahi Evran Üniversitesi Kırşehir Eğitim Fakültesi Dergisi 2009; 10: 213-27.

15. Öner N. Türkiye'de kullanılan psikolojik testler: Bir başvuru kaynağı, [Psychological tests used in Turkey: A reference resource]. 3rd ed. İstanbul: Boğaziçi Üniversitesi Yayınlar1; 1997. p. 5-9.

16. Alacacıoğlu A, Yavuzsen T, Diriöz M, Yeşil L, Bayrı D, Yllmaz U. Kemoterapi alan kanser hastalarında anksiyete düzeylerindeki değişiklikler. Uluslararası HematolojiOnkoloji Dergisi 2007; 17: 87-93.

17. Polychronopoulou A, Divaris K. Perceived sources of stress among Greek dental students. J Dent Educ 2005; 69: 687-92. [CrossRef]

18. Sanders AE, Lushington K. Effect of perceived stress on student performance in dental school. J Dent Educ 2002; 66: 75-81. [CrossRef]

19. Gorter R, Freeman R, Hammen S, Murtomaa H, Blinkhorn A, Humphris G. Psychological stress and health in undergraduate dental students: fifth year outcomes compared with first year baseline results from five European dental schools. Eur J Dent Educ 2008; 12: 61-8. [CrossRef]

20. Dahan H, Bedos C. A typology of dental students according to their experience of stress: a qualitative study. J Dent Educ 2010; 74: 95-103. [CrossRef]

21. Davis EL, Tedesco LA, Meier ST. Dental student stress, burnout, and memory. J Dent Educ 1989; 53: 193-5.

22. Cohen H, Hurwitz M, Lanesman B, Myburg N, Prinsloo $B$. The perception and response to stress by dental students of the University of Witwatersrand. Diastema 1982; 10 : $16-21$.

23. Perera FP, Estabrook A, Hewer A, et al. Carcinogen-DNA adducts in human breast tissue. Cancer Epidemiol Biomarkers Prev 1995; 4:233-8.

24. Silverstein ST, Kritz-Silverstein D. A longitudinal study of stress in first-year dental students. J Dent Educ 2010; 74: 836-48. [CrossRef]

25. Aker S, Midik Ö. The views of medical faculty students in Turkey concerning the COVID-19 pandemic. J Community Health 2020; 45: 684-8. [CrossRef]

26. Bao Y, Sun Y, Meng S, Shi J, Lu L. 2019-nCoV epidemic: address mental health care to empower society. Lancet 2020; 395: e37-8. [CrossRef]

27. Mahdee AF, Gul SS, Abdulkareem AA, Qasim SSB. Anxiety, practice modification, and economic impact among Iraqi dentists during the COVID-19 outbreak. Front Med (Lausanne) 2020; 7:595028. [CrossRef]

28. Ayittey FK, Ayittey MK, Chiwero NB, Kamasah JS, Dzuvor C. Economic impacts of Wuhan 2019-nCoV on China and the world. J Med Virol 2020; 92:473-5. [CrossRef]

29. Peker I, Alkurt MT, Usta MG, Turkbay T. The evaluation of perceived sources of stress and stress levels among Turkish dental students. Int Dent J 2009; 59: 103-11.

30. Özdede M, Sahin SC. Views and anxiety levels of Turkish dental students during the COVID-19 pandemic. J Stoma 2020; 73: 123-8. [CrossRef]

31. Cao W, Fang Z, Hou G, et al. The psychological impact of the COVID-19 epidemic on college students in China. Psychiatry Res 2020; 287: 112934. [CrossRef]

32. Al-Rabiaah A, Temsah MH, Al-Eyadhy AA, et al. Middle East Respiratory Syndrome-Corona Virus (MERS-CoV) associated stress among medical students at a university teaching hospital in Saudi Arabia. J Infect Public Health 2020; 13: 687-91. [CrossRef] 
1. I feel calm

2. I feel secure.

3 I am tense.

4 I am strained.

5. I feel at ease.

6 I feel upset.

7 I am presently worrying.

8. I feel satisfied.

9 I feel frightened.

10. I feel comfortable.

11. I feel self-confident.

12 I feel nervous.

13 I feel jittery.

14 I feel indecisive.

15. I am relaxed.

16. I feel content.

17 I am worried.

18 I feel confused.

19. I feel steady.

20. I feel pleasant.

21. Usually I feel pleasant.

22 Usually I tire nervous and restless.

23 Usually I feel satisfied with myself.

24 I wish I could be as happy as others seem.

25 I feel like a failure.

26. I feel rested.

27. I am calm, cool, and collected.

28 I feel that difficulties are piling.

29 I worry too much over something.

30. Usually I am happy.

31 I am inclined to take things hard.

32 Usually I lack self-confidence.

33. Usually I feel safe.

34 I make decisions easily.

35 I feel inadequate.

36. Usually I am content.

37 Some unimportant thought runs.

38 I take disappointments so keenly.

39. I am steady person.

40 I get in a state of tension or turmoil.

\author{
(1)
}

(1)

(1)
(2)

(2)

(3)

(3)

(4)

(2)

(3)

(4)

(2)

(3)

(4)

(2)

(3)

(4)

(2)

(3)

(4)

(2)

(3)

(4)

(4)

(2)

(3)

(4)

(2)

(3)

(4)

(2)

(3)

(4)

(2)

(3)

(4)

(2)

(3)

(4)

(2)

(3)

(4)

(2)

(3)

(4)

(2)

(3)

(4)

(2)

(3)

(4)

(2)

(3)

(4)

(2)

(3)

(4)

(2)

(3)

(4)

(2)

(3)

(4)

(2)

(3)

(4)

(2)

(3)

(4)

(2)

(3)

(4)

(2)

(3)

(4)

(2)

(3)

(4)

(2)

(3)

(4)

(2)

(3)

(4)

(2)

(3)

(4)

(2)

(3)

(4)

(2)

(3)

(4)

(2)

(3)

(4)

(2)

(3)

(4)

(2)

(3)

(4)

(2)

(3)

(4)

(2)

(3)

(4)

(2)

(3)

(4)

(2)

(3)

(4)

(2)

(3)

(4)

(2)

(3)

(4)

(2) 